\title{
READERS
Insight
}

Journal of Management Info (JMI)

ISSN:2313-3376

www.readersinsight.net/jmi

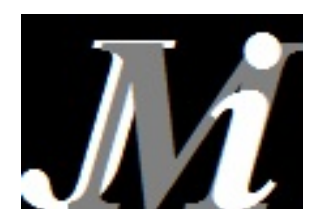

\section{The relationship of clothing with personal identity of different clothing style personalities among working women}

\author{
Bakht Shahida Gillani ${ }^{*}$, Syeda Kaniz-i-Fatima Haider ${ }^{2}$, Farzan Ali Jan ${ }^{3}$ \\ ${ }^{1}$ Government Frontier College for Women, Peshawar \\ ${ }^{2}$ College of Home Economics \\ ${ }^{3}$ COMSATS Institute of Information Technology, Attock
}

*Corresponding author: tazakkagillani@yahoo.com

\begin{abstract}
This study examined how clothing choices are influenced by personal identity. The purpose of this study was to find out relationship of clothing with personal identity among different clothing style personalities. A convenience sample of 300 employed women from Govt., semi Govt., and private colleges, schools, offices and hospitals was selected for the study. In the first phase, women of six clothing style personalities were selected by a questionnaire based on six different choices of clothes and accessories. In the second phase, they were investigated for finding the relationship between their clothing choices and personal identity. A self constructed questionnaire was used for this purpose. Classic, Dramatic, and Natural Style Personalities scored higher on the scale than Romantic, Ingénue, and Gamin Style Personalities. To test the hypothesis, t-test was used that showed significance between Classic Style, Dramatic Style, and Natural Style Personalities (group-I) and Romantic Style, Ingénue Style and Gamin Style Personalities (group-II). It was found by this study that our clothing choices are directly related to personality traits. The study will help people to get information about clothing concept; how clothing will be related to personality impressions and judgments.
\end{abstract}

\section{ARTICLE INFORMATION}

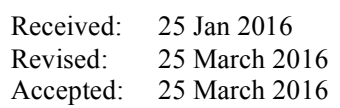

Accepted: 25 March 2016

DOI:

http://dx.doi.org// 10.31580/jmi.v9i1.43

\section{Introduction}

Clothes are one of the basic human needs which completed a human being (Mulaudzi, 2005). Whereas, in words of Johnson et. al., (2002) dress is an accumulation to modify the body and/or supplements to the body. Apparel is defined as a decorative body covering whereas, clothing is a generic term used for any coverings of the human body (Sproles and Burns, 1994). Besides basic human need, clothing plays an important role in our social life human has a strong desire for approval from others which is fulfilled through the clothing choices. Construction of self-identity depends greatly upon one's self-reflection through clothing choices and its appreciation by others. According to Damhorst (1992), patterns of everyday life are reflected in dress. Selection of proper dress and as whole appearance "reflects personal feelings" of a person and communicate about "personal values and values of the society the individual lives in" (Damhorst, 1992).

Some people copy others. They imitate their peer group. They mould their personalities according to their habit of following others. They are called imitators. Some people create new styles that are followed by others. They have creative personalities and are called innovators and trend setters. Clothing says almost all about the wearer. It gives a picture of one's personality. Dress and appearance allow others to derive various cues about the wearer including personal information. "Dress communicates about personal and social values of its wearer" (Damhorst et al, 1999). Result from the study by Dixon (2007) found that dress and appearance is influenced by fashion leadership, self confidence, and self consciousness. According to Coughlin (2009) fashion trend setters, and fashion followers are the two main categories of the world of fashion. Selection of clothing fashion may also be influenced by different type of individuals' personalities which are categorized in different studies in different ways; the six personality styles or Six Clothing Style Personalities are commonly discussed in different studies. According to Gibson (2012), "it is believed that there are some personality types that influence the fashion choices." Classic people are happy in the styles that are comfortable to them whether new or adopted from old fashion. He pointed that "classic characters give the impression of old-fashioned and a dramatic character is one who undergoes change". The six personality styles are explained by Gibson (2012) as: Classic styles are worn by emotional nature, balanced, controlled and rational personalities. Romantic style is worn by artistic, enchanting, and magnetic persons. Ingénue style is also liked by artistic and charming personalities. Dramatic styles are used by natural authority, in control, and risk taker. Natural styles are worn by warm and friendly, goal oriented, and responsible people. Gamin style is liked by energetic, dynamic, and fast mover. The present study is going to find the point of views of women of the six style personalities about their clothing choices. Also to analyze how their personal identity would influence their clothing choices. Some people are very active and energetic they use to wear accordingly. Clothing depicts personality of the wearer. Hethorn (1994) argued that what we look like and how we choose to present ourselves is a silent form of communication. There was keen interest of the researcher to find out what would be there behind the "silent form of communication" that influences the individuals to be explored due to their clothing and fashion choices. It may be assumed 
that there are so many personality traits of people which may work for persuading them for getting their appearance. "Inferences can be made about the individual's personality traits, demographic and social position, and even intentions or motives through the overall appearance and dress of an individual" (Johnson, et. al.,2002). Clothing has a great impact on our life. The way we dress shows our inner feelings, life style, our tastes, and our knowledge of current trends. Clothing gives a picture of one's personality. Proper selection of clothes helps people feel good about them and has great impact on their personalities. Doyle (2012) argued that well-dressed people feel better about themselves.

By the use of products consumers satisfy their psychological needs: strengthening and explicating self-identity, and helping to establish one's individuality (Escalas, 2004). Personal identity is one of the basic human psychological needs. Every human is in fact unique by nature who desire strongly to be identified in the crowd. Individuals may express their unique personalities through their apparel and fashion (Goldsmith, et.al., 1996). Consumers seek for uniqueness to look different from others "through selecting brands that enhance their individual self along with their image at social level" (Gold smith and Clark, 2008). Personality plays an important role in this respect. It is human personality that discriminates and dominates them over other creatures. Personality is composed of person's physique, ones posture and appearance. The use of different clothes, accessories, and cosmetics are used as an aid to the personality which make a person unique among others. Clothes say silently so much about its wearer. It gives individuals their identity and show their feelings and emotions as well. It is found by Biecher et. al., (1999) that apparel represents as a symbol of who that individual is or aspires to be. A generalized view of the researchers about clothing choices is to enhance consumers' image and to communicate their identity to others (Auty and Elliot, 1998; Mickinney et al., 2004)

Through best choice of clothing people feel good about themselves it gives them satisfaction to express their inner positive feelings to others. Niinimaki (2010) argued the same points as, "clothing choices may not only allow individuals to strengthen their inner self, and identity at social interaction but also at an emotional level." Whereas, Kaiser (1990) stated in other words, "fashion blends us with our emotional needs; it communicates our inner individual personality to others." the consumers adapts and modifies fashion styles and make rules to help in creating their own individuality in order the garment better expresses their identity, values, and emotions (Uotila, 1995).

\section{Hypotheses}

1. The impact of clothing will be more positive on personal identity of Classic, Dramatic, and Natural style personalities as compared to Romantic, Ingénue, and Gamin style personalities.

\section{Methods}

\section{Sample}

A sample of 300 working women at the age of 25 to 60 years was selected from different Govt., semi Govt., and private colleges, schools, and offices of Peshawar district. The respondents were selected on the basis of their availability through convenient sampling technique. The researcher made visit to some of the respondents at their residence and the rest were interviewed at their place of work.

\section{Instruments}

\section{Demographic information sheet}

A self constructed demographic sheet was composed to get information regarding age, qualification, social status, and occupation.

\section{Clothing personality checklist}

A clothing checklist based on six different choices of dresses and accessories was composed for the scrutiny of six clothing personalities.

\section{Self-constructed questionnaire}

A self devised questionnaire consisting of 21 items answered on two point scale with agree and disagree was constructed to get information about the impact of clothing on personal identity of six different Clothing Style Personalities.

\section{Procedure}

For the purpose of data collection, different instruments were administered to get information about the impact of clothing on personal identity of working women having six different clothing style personalities - Classic style, Romantic style, Ingénue style, Dramatic Style, Natural style and Gamin Style. In the first phase 300 respondents of six Clothing Style Personalities (50 from each group) were scrutinized by a questionnaire based on six different choices of dresses and accessories. In the second phase, the respondents were interviewed through a self devised questionnaire consisted of 21 items to get information about the relationship of clothing with personal identity of six different Clothing Style Personalities. Classic, Dramatic and Natural Style Personalities got high score as compared to Romantic, Ingénue, and Gamin Style Personalities.

\section{Statistical Analysis}

For statistical analysis, t-test was applied on the data that showed significance between Classic, Dramatic and Natural Style Personalities (Group-I) and Romantic, Ingénue, and Gamin Style Personalities (Group-II). The analysis was carried out by using standard statistical package of SPSS.

\section{Results}

Descriptive statistics of the data is presented for general trends. Mean scores were calculated for the instrument: self constructed questionnaire Test. Table 1 represents mean and standard deviations of the variables. The table also reveals the degree of reliability of the measure (.69). The results confirmed that the questionnaire used in the present study was reliable and its items were internally consistent.

Table 1: Alpha Reliability Coefficient and Descriptive Statistics of Personal Identity and Clothing Questionnaire $(N=300)$

\begin{tabular}{lllll}
\hline Scales & Items & A & Mean & SD \\
\hline PICQ & 21 & .69 & 9.11 & 2.59 \\
\hline
\end{tabular}

Findings of the study revealed that Classic Style, Dramatic Style, and Natural Style Personalities got high score on questionnaire measuring personal identity in relation with clothing as compared to Romantic, Ingénue, and Gamin Style Personalities.

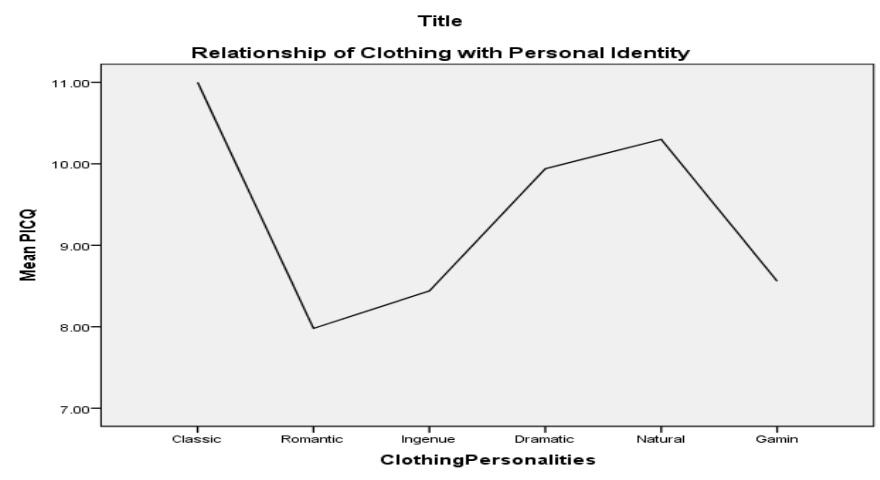

Fig. 1.

The line chart given in Fig: 1 illustrates the mean of scores on PICQ of the Six Clothing Personalities. Values 7 to 11 denote mean range of the scores. Value 9 and above 9 shows high relationship of clothing choices with personality. Mean of values for PICQ is 11.0 for Classic Style Personalities, 8.0 for Romantic, 8.4 for Ingenue, 9.8 for Dramatic, 10.3 for Natural, and 8.5 for Gamin Style Personalities as shown in the figure. The figure confirmed that majority of the 
respondents of Classic, Dramatic, and Natural Style Personalities score high on Personal Identity and Clothing Questionnaire. Whereas, respondents of Romantic, Ingenue, and Gamin Style Personalities score low on the scale for identifying the relationship of clothing with personal identity.

Table 2: Mean difference and t-value of Classic, Dramatic, and Natural Group and Romantic, Ingenue, and Gamin Group on the Score of PICS $(N=300)$

\begin{tabular}{|c|c|c|c|c|c|}
\hline Group & $\mathbf{N}$ & $\mathbf{X}$ & SD & $t$-value & $p$-value \\
\hline $\begin{array}{l}\text { Classic, } \\
\text { Dramatic, } \\
\text { and Natural }\end{array}$ & 150 & 1.826 & .378 & & \\
\hline $\begin{array}{l}\text { Romantic, } \\
\text { Ingenue, and } \\
\text { Gamin }\end{array}$ & 150 & 1.540 & .500 & 5.591 & .000 \\
\hline
\end{tabular}

Note. The lower the score on the questionnaire the lesser their ability will be to select clothing according to their personality.

Above Table 2 shows the mean differences between Classic, Dramatic, and Natural group and Romantic, Ingenue, and Gamin group on the score of personal identity in relation with Clothing. The above Table also indicates the total number of the sample, the means, and standard deviations of the scores of self constructed questionnaire for findings of relationship of Personal Identity with Clothing choices (PICQ) for studying the personality of the respondents.

The figure shows that Romantic, Ingenue, and Gamin group shows lower mean, which specify that their ability to select clothes in accordance with their personalities is less as compared to Classic, Dramatic, and Natural group. This mean difference .286 is highly statistically significant.

\section{Discussion}

Personality is the most important aspect to be considered while selecting clothes. It is human personality that discriminates an individual over other. Clothing plays a significant role in augmenting the personality. A generalized view of the researchers about clothing choices is to enhance consumers' image and to communicate their identity to others (Mickinney et al., 2004). Depending upon the clothing choices, the sample was investigated to find out differences in their personality. A self devised questionnaire consisting of twentyone questions was administered to study the impact of clothing in upholding personal identity among different Clothing Style Personalities. Statistical analysis of the data showed that $68.3 \%$ of the respondents select their clothing according to their personality while $31.7 \%$ of the respondents had low score on the Personal Identity and Clothing Questionnaire (PICQ). The results were further analyzed by using t-test. Table 2 shows the mean differences between Classic, Dramatic, and Natural Personalities (group-I) and Romantic, Ingenue, and Gamin Personalities (group-II) on the score of PICQ. Group-II shows lower mean, which specify that their ability to select clothes in accordance with their personalities is less as compared to group-I. The mean difference .286 is highly statistically significant. The line chart given in Fig: 5 illustrate the mean of scores on PICQ of the Six Clothing Personalities. This figure also confirmed that majority of the respondents of Classic, Dramatic, and Natural Style Personalities score high on Personal Identity and Clothing Questionnaire. Whereas respondents of Romantic, Ingenue, and Gamin Style Personalities scored lower on the Questionnaire for identifying the relationship of clothing with personal identity. It was because of the specific personality type of the respondents that influenced their clothing choices. For example, "classic characters give the impression of oldfashioned and a dramatic character likes a change (Gibson, 2012) The above mentioned results clearly represents the hypothesis of the study, "the impact of clothing will be more positive on personal identity of Classic, Dramatic, and Natural style personalities as compared to Romantic, Ingénue, and Gamin style personalities."
It may be concluded from the results of the current study that the respondents with high score on the Personal Identity and Clothing Questionnaire select their clothing and accessories mostly according to their personalities and get higher satisfaction from its consumption. Whereas respondents who obtained low scores on the same scale do not consider their personalities important while their selection of clothing or may not be aware about their personal identity as well.

This study will help in providing knowledge about textile and clothing fashion. In the literature review no such study has been detected that explored about the different clothing personalities and about their profiles. One of the objectives of this study was to identify different clothing personalities in Peshawar district that will give support to such studies in other regions of Pakistan as well.

\section{Conclusion}

There is great clothing variation among different Clothing Style Personalities.

Classic, Dramatic, and Natural Style Personalities had high score on Personal Identity and Clothing questionnaire as compared to Romantic, Ingenue, and Gamin Style Personalities.

\section{Suggestions}

This study may be helpful in yielding relevant information about fashion to women seeking for knowledge to improve themselves through best selection of clothes and accessories.

The findings of this study may provide valuable implications for fashion marketers and manufacturers to make more attractive fashion styles to appeal the interested consumers.

This research may fill a gap in the literature by finding the relationship of clothing with personal identity among different personalities. It may provide useful information for future studies that can be developed in other countries or in cross-culture context.

\section{References}

Auty, S. \& Elliot, R.(1998) Fashion involvement, self-monitory and the meaning of brands, Journal of Product \& Brand Management, 7, 109-123.

Biecher, E., Keaton, P.N., \& Pollman, A.W. (1999) Casual dress at work. SAM Advanced Management Journal, 64(1) 17-20

Coughlin, C. Body Image, Self-Esteem, and Consumer Need for Uniqueness as Antecedents to Self Identification as Fashion Opinion Leader vs. Fashion Opinion Seeker. Master's Thesis. The Ohio State University. 2009.

Damhorst, M.L. (1999) Introduction. In Damhorst, M.L., Miller, K.A., \& Michelman, S.O.(Eds.), The meaning of dress, pp. 1-11.New York: Fairchild Publication, Inc.

Dixon, D.L. The influence of values and other social and psychological factors on the dress and appearance of African American college students. Ph.D. These. Louisiana State University and Agricultural and Mechanical College. 2007 pp.78-80.

Doyle, J. R. (2012). Words of wellness: You are what you wear. Retrieved October 24, 2013, from $\mathrm{http} / / \mathrm{www}$. foxnews.com/archives/author/index.html

Escalas, J. (2004). Narrative processing: building consumer connections to brands. Journal of Consumer psychology, 14, 168-180.

Gibson, J. (2012). Bodies that matter: Stock personalities in literature and fashion. Retrieved August 18, 2013, from http://suite101.com/article/bodies-that-matter- stock-personalities.

Goldsmith, R.E., Flynn, L.R., \& Moore, M.A. (1996) The self-concept of fashion leaders. Clothing and Textiles Research Journal, 10(1), 37-45.

Goldsmith, R.E. \& Clark, R.A. (2008) an analysis of factors affecting fashion opinion leadership and fashion opinion seeking. Journal of Fashion Marketing and Management, 12(3), 308-322.

Hethorn, J. (1994). Gang identity or self-expression? Researchers look beyond the surface of "Gang Clothing" and appearance. Retrieved November 11, 2011, from http://ucanr.org/repository/cao/index.cfm

Johnson, K.K.P., Schofield, N.A., Yurchisin, J. 2002) Appearance and dress as a source of information: A qualitative approach to data collection. Clothing and Textiles Research Journal, 20 (3), 125-137.

Kaiser, S. (1990) The Social Psychology of Clothing. Symbolic Appearance in Context, $2^{\text {nd }}$ edn. Macmillan: New York; USA. 
Mickinney, L., Legette-Traylor, D., Kincade, D. \& Holloman, L. (2004) Selected social factors and the clothing buying behavior patterns of black college consumers. International Review of Retail, Distribution and Consumer Research, 14, 389-406.

Mulaudzi, T. Buying Patterns of Clothing during Early Adolescence: An exploratory study. Masters. Thesis. University of Pretoria etd, 2005.

Niinimaki, K. (2010). Eco clothing, consumer identity and ideology. Sustainable Development. 18, 150-160.
Sproles, G.B., \& Burns, L.D. (1994) Changing appearances: Understanding dress in contemporary society, p.7. New York: Fairchild Publication, Inc. Uotila, M. (1995) Image of clothing - the ways of being. In Clothing and Its Social, Psychological, Cultural, Envirnmental, Aspects, Proceedings of Textiles, Clothing and Craft Design, Helsinki, 1995, Suojanen U. (ed.). University of Helsinki; 93-105 